\title{
FILM PENDEK ALAT PENGKAJIAN KESEHATAN KELUARGA KHON KAEN UNIVERSITY
}

\author{
${ }^{1}$ Suwarno, ${ }^{2}$ DaruneeJongudomkarn
}

\begin{abstract}
${ }^{1}$ Master of Family Nursing, Faculty of Nursing, Khon Kaen University, Thailand Email: Suwarno.m787@gmail.com, Alamat: Jalan RingRoad Barat, Ambarketawang, Gamping, Kec. Sleman, Daerah Istimewa Yogyakarta.

${ }^{2}$ Assoc. Prof. of Family Nursing, in Faculty of Nursing, Khon Kaen University, Thailand email: darjonster@gmail.com, 123 Moo 16 Mittapap Rd., Nai-Muang, Muang District, Khon Kaen 40002, Thailand.
\end{abstract}

\begin{abstract}
Background:Family health care in family nursing is focused on a holistic health care view. A holistic health carewill be achieved if the family health nursing care is properly executed. The continuing education is appropriate to increase the family health assessment application and understanding. It consists of training programs, which might take advantage of a video as a learning media.

Objective:The objective of the study was to produce the KKU FHA tool short movie based on the 3 phases; pre-production, production and post-production.

Methods:Five nursing educators reviewed the video and evaluateit with a form in a Likert scale.

Result: This video was in MOV format, sized1.12 GB, the picture size was 1280x720, codec H.264, AAC, length of time was 16.53 minutes and could be opened in smartphone andcomputer. The mean score of the evaluation form was 3.6 for the quality of sound and 4.8 for the benefit of the video. The total mean score was 45.8 out of55.

Conclusion:The KKU FHA tool short video was appropriate and could be implemented ina try-out or a training program, and couldalsobe developed and improvedto achieve the best quality of sound and picture.
\end{abstract}

Keywords: family health assessment, KKU FHA Tool, training, short movie

\section{PENDAHULUAN}

Pengkajian keluarga adalah salah satu kunci untuk mengidentifikasi data permasalahan dan kebutuhan dari permasalahan keluarga serta sebagai data pendukung dalam perencanaan perawatan kesehatan keluarga. Banyak penelitian menyebutkan bahwa pengkajian kesehatan keluarga penting. Pengkajian kesehatan keluarga bermanfaat untuk mengkaji kebutuhan dan permasalahan kesehatan keluarga, membantu pengkajian persepsi fungsi keluarga, mengevaluasi pengalaman dan persiapan pasien. ${ }^{(1-3)}$

Penerapan pengkajian kesehatan keluarga akan dipengaruhi oleh Nursing intellectual Capital yang terdiri atas dua komponen yaitu Nursing Structural Capital dan Nursing Human Capital. ${ }^{(4-6)}$ Nursing Structural Capital di Indonesia salah satunya adalah UU Keperawatan No. 38 tahun 2014, yang menyebutkan bahwa perawat berperan melakukan perawatan kesehatan secara personal, keluar-ga, dan masyarakat. Komponen ke-dua yaitu Nursing Human Capital yang berkaitan dengan pendidikan lanjutan salah satunya adalah program pelatihan.

Pelatihan terkait dengan pengkajian kesehatan keluarga untuk perawat masih dibutuhkan untuk meningkatkan penampilan perawat baik pengetahuan, keterampilan, sikap maupun pengalaman perawat. $^{(7)}$ Program pelatihan merupakan salah satu elemen kegiatan dari participatory learning 
processyang juga didukung oleh communication elementkhususnya communication methods yang salah satunya adalah video sebagai media pembelajaran. ${ }^{(8)}$

Pada penelitian inovasi ini, peneliti menggunakan pengkajian kesehatan keluarga Khon Kaen University(KKU FHA tool) di dalam video karena ingin memperkenalkan KKU FHA tool kepada tenaga kesehatan di ASEAN, mudah digunakan, menggunakan gambar dan symbol, serta dapat diterapkan di klinik maupun institusi pendidikan. ${ }^{(9-11)}$

Berdasarkan penjelasan di atas, peneliti tertarik untuk menghasilkan sebuah film pendek tentang penggunaan alat pengkajian kesehatan keluarga Khon Kaen University sebagai acuan untuk para perawat yang bekerja di RS, Puskesmas, maupun di institusi pendidikan di Yogyakarta, melalui 3 tahapan pengembangan yaitu Pre-Production, Production, dan Post-Production. ${ }^{(12)}$

\section{BAHAN DAN CARA PENELITIAN}

Video dalam penelitian ini merupakan bagian dari program pelatihan terkait dengan $K K U$ FHA tool yang telah disetujui oleh kode etik penelitian Khon Kaen University(ethical committee of human research International Review Board Khon Kaen UniversityThailand) dengan nomor referensi HE582265 dan nomor IRB 00001189, LPPM STIKES Achmad Yani Yogyakarta-Indonesia, BAPPEDA Daerah Istimewa Yogyakarta, dan BAPPEDA Bantul dan Kulonprogo, Yogyakarta Indonesia.Proses pembuatan video berdasarkan tiga tahapan yaituPreProduction, Production, danPostProduction. $^{(12)}$

Tahapan pertama adalah Pre-production (mengembangkan naskah video, menetapkan judul, memilih pemeran, memutuskan tempat pengambilan gambar, penerjemahan bahasa jika diperlukan). Film pendek ini dibuat di Yogyakarta; rumah kos-kosan di Gamping, Puskesmas Pandak 1 dan Danau Plastik, Khon Kaen University, Thailand. Proses pembuatan video selama 1 bulan lebih 2 minggu.

Pemilihan pemeran dipilih berdasarkan kriteria; bersedia menjadi pemeran dalam video, mahasiswa ilmu keperawatan (S1), dan perawat puskesmas. Peran di dalam film pendek ini yaitu ayah, ibu, anak, perawat dan pembaca narasi (sesi perkenalan dan pendahuluan). Penulisan naskah film menggunakan naskah tabel, dikembangkan oleh penulis yang terdiri atastiming, footage dialogue, dan movie effects.

Kedua adalah tahap Production (pengaturan tempat, persiapan alat, dan proses pengambilan gambar atau video). Alat pendukung dalam pembuatan film pendek ini yaitu naskah film yang terdiri dari penjelasan KKU FHA tool, percakapan keluarga, pengkaji-an keluarga melalui lima komponen dari KKU FHA tool (genogram, ecomap, familyattachment, family tree-wellbeing, dan five key questions) dan sesi terakhir adalah kesimpul-an. Alat rekam menggunakan handycam dan kamera handphone. 
Proses terakhir adalah Post-Production (melihat kembali hasil rekaman film, mengolah hasil rekaman film, menambahkan subtitle jika dibutuhkan, menambahkan efek film (gambar, suara dan perpindahan gambar). Proses analisa film menggunakan $I$ Movie project video untuk Mac versi 9.0.9, dimodifikasi tanggal 21 Mei 2013.

\section{Proses Analisis Film}

Lima perawat ahli telah dipilih berdasarkan kriteria minimal latar belakang pendidikan adalah S2, memahami budayalndonesia, memahami keperawatan keluarga serta komunitas. Lima perawat ahli menilai hasil video dengan mengisi di lembar evaluasi dengan 5 poin skala Likert (1=lemah, 2=cukup, 3=baik, 4=sangat baik, 5= luar biasa). Lembar evaluasi video terdiri dari 11 item pernyataan untuk mengkaji isi, rancangan tekhnik, dan kelayakan video. Seluruh hasil analisa berdasarkan dari perhitungan rata-rata nilai dari hasil lembar evaluasi para ahli. Saran dan komen dari para ahli juga tersedia di lembar evaluasi tersebut.

\section{HASIL DAN PEMBAHASAN}

Film pendek tentang alat pengkajian kesehatan keluarga telah ditinjau dan dinilai oleh lima perawat ahli selama dua kali berdasarkan saran dan komen dari para ahli. Film pendek ini berdurasi 16 menit, 53 detik, terdiri dari 1 aktor, 3 aktris dan 1 narator. Percakapan dalam film pendek ini menggunakan Bahasa Indonesia dengan subtitle Bahasa Inggris untuk memudahkan penonton dari Negara lain dalam memahami percakapan film. Hasil film pendek ini memiliki format MOV, dengan ukuran file 1,12 GB, ukuran gambar 1280x720, codec H.264, AAC, waktu 16,53 menit dan dapat diputar di Smartphone dan komputer. Film ini juga dapat di upload di You tube, Facebook dan Gmai

\section{Hasil evaluasi video}

Hasil evaluasi video dapat dilihat pada tabel 1. Nilai rata-rata terendah 3.6 terkait dengan kualitas suara dan nilai rata-rata tertinggi yaitu 4,8 tentang manfaat video. Jumlah total nilai rata-rata lembar evaluasi video berdasarkan para ahli adalah 45,8 dari total 55 .

Video penelitian ini menghasilkan sebuah film pendek berdurasi 16 menit 53 detik berisi tentang bagaimana kisah sebuah keluarga, penjelasan 5 komponen KKU FHA tool, dan sesi penutup berisi rangkuman. Berdasarkan hasil evaluasi nilai rata-rata terendah adalah 3,6 terkait dengan kualitas suara dan nilai tertinggi pada kegunaan video yaitu 4,8. Hal tersebut mengindikasikan bahwa hasil evaluasi berguna dan layak untuk diterapkan akan tetapi masih membutuhkan peningkatan kualitas suara video. Pengaturan video dapat ditingkatkan dari 100\% menjadi lebih 100\% untuk suara musik dan 500\% untuk pengaturan suara aktor dan aktris. 
Tabel Hasil Lembar Evaluasi Video Oleh Para Ahli Berdasarkan Perhitungan Rata-Rata.

\begin{tabular}{|c|c|c|c|c|c|c|}
\hline \multirow[t]{2}{*}{ ITEM } & \multicolumn{3}{|c|}{ PENGKAJI } & \multirow[b]{2}{*}{4} & \multirow[b]{2}{*}{5} & \multirow{2}{*}{$\begin{array}{l}\text { RATA- } \\
\text { RATA }\end{array}$} \\
\hline & 1 & 2 & 3 & & & \\
\hline \multicolumn{7}{|l|}{ Isi } \\
\hline 1. Akurat & 4 & 4 & 4 & 4 & 5 & 4.2 \\
\hline 2. Kegunaan & 5 & 5 & 4 & 5 & 5 & 4.8 \\
\hline 3. Kejelasan Tujuan & 4 & 5 & 3 & 4 & 5 & 4.2 \\
\hline 4. Presentasi isi & 4 & 4 & 3 & 4 & 5 & 4 \\
\hline \multicolumn{7}{|l|}{ Produksi tekhnis } \\
\hline $\begin{array}{l}\text { 1. Rancangan umum video dan } \\
\text { ciri-cirinya }\end{array}$ & 4 & 5 & 3 & 5 & 5 & 4.4 \\
\hline 2. Kualitas gambar & 3 & 4 & 4 & 4 & 5 & 4 \\
\hline 3. Kualitas suara & 3 & 2 & 4 & 4 & 5 & 3.6 \\
\hline $\begin{array}{l}\text { 4. Keselarasan antara suara } \\
\text { dan gambar }\end{array}$ & 4 & 2 & 4 & 5 & 5 & 4 \\
\hline \multicolumn{7}{|l|}{ Kelayakan } \\
\hline 1. Akting & & & & & & \\
\hline 2. Kelayakan untuk penonton & 4 & 4 & 3 & 3 & 5 & 3.8 \\
\hline 3. menarik & 4 & 4 & 4 & 5 & 5 & 4.4 \\
\hline 4. kepuasan & 5 & 4 & 4 & 4 & 5 & 4.4 \\
\hline Total & 44 & 43 & 40 & 47 & 55 & 45.8 \\
\hline
\end{tabular}

Selama tahap pre-production, cameramen seharusnya dalam pengambilan video menggunakan posisi horizontal bukan vertikal. Hal ini akan bermanfaat untuk meningkatkan kualitas gambar dan suara video. Pengaturan tempat pengambilan video masih perlu membutuhkan persiapan pencahayaan dan alat rekam lebih dari satu, sehingga video dapat diambil dari berbagai sisi. Selain itu, kualitas kamera juga dibutuhkan dalam pengambilan gambar. Dihubungkan dengan post-production, penggunaan aplikasi pembuatan video merupakan hal terpenting dalam pembuatan film. Sehingga kombinasi antara pengambilan gambar dapat berkualitas tinggi.
Semua hasil nilai rata-rata evaluasi video dari lima perawat ahli yaitu 45.8/55 yang berarti film pendek ini mempunyai kualitas yang sangat baik, bermanfaat, dan dapat diterapkan menjadi salah satu paket program pelatihan KKU FHA tool untuk memperkenalkan alat pengkajian kesehatan keluarga dan meningkatkan penampilan perawat (pengetahuan, keterampilan, sikap, dan pengalaman) dalam pengkajian kesehatan keluarga. Video dapat digunakan sebagai media untuk memotivasi, memengaruhi penonton dan sebagai media pembelajaran karena bersifat menyenangkan, merangsang, dan kreatifitas media yang akan memudahkan penonton dalam memahami isi materi. ${ }^{(13)}$ 
Video adalah salah satu media pendidikan yang dapat dilihat setiap waktu oleh penonton dan dapat digunakan sebagai media tambahan dalam metode pembelajaran sederhana. Menggunakan video yang lebih kreatif dan akan menarik penonton. Pembuatan film dengan durasi pendek dapat mencegah kebosanan penonton ketika melihat film dan dapat diunggah secara mudah ke internet dan mudah disebarluaskan. Kelebihan yang lain adalah video ini telah dinilai oleh lima perawat ahli.

Ada beberapa kualitas gambar video yang tidak cukup bagus karena bukan gambar original. Video tersebut didapat dari video hasil kiriman lewat media ke dua. Kurangnya pengalaman dalam pengambilan video membuat kualitas gambar dan suara tidak cukup baik. Gambaran cerita keluarga di dalam video kurang cukup kuat untuk menggambarkan permasalahan di dalam keluarga. Kelemahan yang terakhir adalah perlu adanya subtitle disetiap tahapan dari lima komponen KKU FHA Tool di dalam percakapan antara perawat dan pasien.

\section{PERSEMBAHAN}

Kami mengucapkan terimakasih kepada Lembaga Pengelola Dana Pendidikan (LPDP) yang telah memberi- kan beasiswa thesis dan mendukung perjalanan pembuatan penelitian ini. STIKES Jenderal Achmad Yani Yogyakarta yang telah memberikan bantuan dana pendidikan dan kesempatan kepada penulis untuk menyelesaikan tugas belajar Magister Keperawatan di Fakultas Keperawatan, Khon Kaen University Thailand.

\section{KEPUSTAKAAN}

1. Friedman, M. M., Bowden, V. R., \& Jones, E. G. Family nursing: Research, theory \& practice (5th ed.) Upper Saddle River, NJ: Prentice Hall/Pearson Education. 2003.

2. Fok, C.C.T., Allen, J., Henry, D., and Team. The brief family relationship scale: A brief measure of th relationship dimension in family functioning: SAGE. 2011.

3. Steinhauser, K.E., Voils, C.I., Bosworth, H.B., and Tulsky, J.A. Validation of a measure of family experience of patients with serious illness: The QUAL-E (Fam). Journal of Pain and symptom management. 2014.

4. Covell, C.L. Outcomes achieved from organizational investment in nursing continuing professional development. Journal of Nursing Administration,2009. 39(10), 438-443.

5. Covell, C.L. The Relationship of Nursing Intellectual Capital to the Quality of Patient Care and the Recruitment and Retention of Registered Nurses. Toronto; Faculty of Nursing Toronto. 2011. 
6. Covell, C.L., \& Sidani, S. Nursing Intellectual Capital Theory: Implications for Research and Practice. OJIN: The Online Journal of Issues in Nursing, 2013. 18(2), Manuscript 2.

7. Forehand, M. Bloom's taxonomy: Original and revised. In M. Orey (Ed.), Emerging perspectives on learning, teaching, and technology. 2005. Available Website: <http://www.coe.uga.edu/epltt/bloom.htm.>

8. Kaewjumnong, C. The Model Development Of Participatory Learning Process Related to Community Environmental Management. European Scientific Journal, 2013. 9(2), 232-240.

9. Jongudomkarn, D., Juntawong, N., Rajchai, L., Turnkaew, W., \& Buakhaw, W. Contruct validity of the Khon Kaen University Family Health Needs and Problems Assessment Tool (KKU FHeNPAT): Case studies of the informal sector Families in Isan. Journal of Nursing Science \& Health. 2010.

10. Jongudomkarn, D., Prungkamma, P., Kaewprom, Y., Khomkhum, S., and Konsila, $U$. The construct validity of KhonKaen University family quality of life scale: An Exploratory factor analysis. Journal of nursing science health. 2011.

11. Jongudomkarn, D., \& Macduff, C. Development of a family nursing model for prevention of cancer and other noncommunicable disease through and appreciative inquiry. Asian Pacific Journal of Cancer p Prevention, 15.2014.
12. Corbally, A.M. Considering video production? Lessons learned from the production of a blood pressure measurement video. Nurse Education in Practice, 2005. 5, 375-379.

13. Koumi, J. Designing video and multimedia for open and flexible learning. London: Routledge. 2006. 